\title{
Silent renal infarcts prompt further investigation
}

\author{
Aine Peoples, ${ }^{1}$ Richard Baer, ${ }^{2}$ Daniel Schweitzer, ${ }^{3}$ Gregory Amos ${ }^{4}$
}

${ }^{1}$ General Medicine, Mater Hospital Brisbane, Brisbane, Queensland, Australia ${ }^{2}$ Renal, Mater Hospital Brisbane, Brisbane, Queensland, Australia ${ }^{3}$ Centre for Neurosciences, Mater Misericordiae Brisbane Ltd, South Brisbane, Queensland, Australia ${ }^{4}$ Queensland X-Ray Pty Ltd, South Brisbane, Queensland, Australia

\section{Correspondence to} Dr Aine Peoples; peoplea@tcd.ie

$A P, R B$ and DS contributed equally.

Accepted 20 February 2020

\section{DESCRIPTION}

A 76-year-old, right-handed, Caucasian woman presented with influenza A and diarrhoea. Medical history includes trigeminal neuralgia, dyslipidaemia, hypertension and hypothyroidism. The patient's regular medications included thyroxine, atenolol, atorvastatin, pregabalin and valproate. Family history was unremarkable. A CT abdomen pelvis was performed to investigate diarrhoea. Incidentally, the patient was found to have multiple renal infarcts (figure 1). This was in the setting of new-onset atrial fibrillation, presumably due to infection. Bloods revealed elevated lactate dehydrogenase (LDH) consistent with acute renal infarcts and preserved renal function. Subsequently, she was found to have confusion, poor calculation, recall and a left upper homonymous quadrantanopia. She proceeded to have an MRI brain. This revealed multiple vascular territory infarcts, which involved in the right

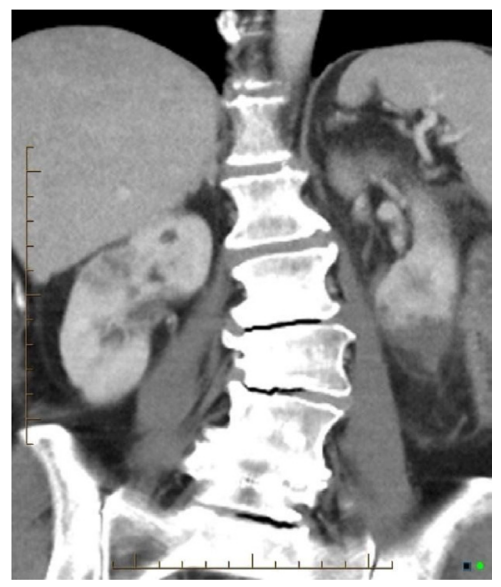

Figure 1 Multiple renal infarcts.

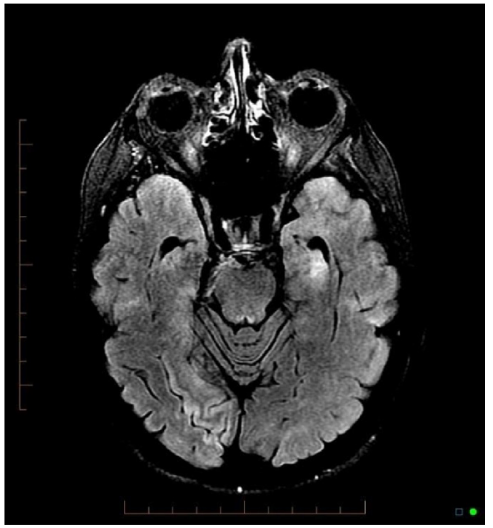

Figure 2 MRI fluid attenuation inversion recovery (FLAIR)—multiple cerebral infarcts.

\section{Patient's perspective}

Given patient's persistent cognitive impairment, we gained some perspective from the patient and her husband (and carer):

Patient: Thank goodness it wasn't worse than it was, in that I don't need a walking stick or anything like that.

Patient's husband: It has affected memory, increased anxiety, and has certainly affected her cognitive ability but has not affected her physical ability, and in that respect I feel this is a slight stroke and she got off lightly. The effect on vision is not severe. I'm lucky, it could have been so much worse. Surprised by the diagnosis as had put it down to symptoms of flu and a recent cruise.

\section{Learning points}

- The renal infarcts were silent in that there was no pain, no rise in serum creatinine, and the lactate dehydrogenase (LDH) rise could be considered non-specific. Her confusion could have been attributed to delirium in the context of acute infection and her cerebral infarcts may have easily gone undetected.

- The areas of infarct involved multiple vascular territories, supporting an embolic aetiology, likely secondary to atrial fibrillation. However, for completeness thrombophilia, vasculitic and antiphospholipid screens were done and found to be negative.

- How often is this occurring? And how often do they occur together? This case reports highlights the need to have a low threshold for neuroimaging in patients with new-onset neurological deficits, including delirium, in the setting of other systemic areas of infarction and in the presence of other risk factors for embolism including atrial fibrillation. The case also highlights the clinical utility of assessing LDH. It is the first to our knowledge of silent renal infarction presenting in association with cerebral infarction, with preserved renal function, although we suspect that this is both an under-recognised and underappreciated clinical phenomenon. Previous cases have been reported but patients were symptomatic or developed renal impairment associated with the renal infarcts. ${ }^{1-3}$

mesial temporal lobe extending to the occipital lobe, left thalamus and left mesial temporal lobe (figure 2). Specific neurology matched the territories infarcted, demonstrated well on figure 2 . This 
woman was anticoagulated for her atrial fibrillation with apixaban. Unfortunately, her cognitive impairment has persisted.

Contributors The initial manuscript was drafted by AP, with editing by both DS and RB. GA (consultant radiologist) gave advice regarding image selection. Information was gathered by first three authors listed and RB obtained consent from the patient.

Funding The authors have not declared a specific grant for this research from any funding agency in the public, commercial or not-for-profit sectors.

Competing interests None declared.

Patient consent for publication Obtained.
Provenance and peer review Not commissioned; externally peer reviewed.

\section{REFERENCES}

1 Adhikari S, Paudel K, Pandit K, et al. Acute renal infarction and cardioembolic stroke in a patient with atrial fibrillation and hyperthyroid-induced cardiomyopathy: a case report. J Med Case Rep 2016;10:117.

2 Kim JH, Kang C, Moon HJ, et al. Multiorgan with renal infarction following treatment of cerebral infarction. Ann Rehabil Med 2013;37:567.

3 Ghassemi A, Bharadia J, Liu A. Acute renal infarction, transient ischemic attack, and biventricular thrombi secondary to substance use disorder: a case report. Clin Case Rep 2019:7:861-4.

Copyright 2020 BMJ Publishing Group. All rights reserved. For permission to reuse any of this content visit

https://www.bmj.com/company/products-services/rights-and-licensing/permissions/

BMJ Case Report Fellows may re-use this article for personal use and teaching without any further permission.

Become a Fellow of BMJ Case Reports today and you can:

- Submit as many cases as you like

- Enjoy fast sympathetic peer review and rapid publication of accepted articles

- Access all the published articles

Re-use any of the published material for personal use and teaching without further permission

Customer Service

If you have any further queries about your subscription, please contact our customer services team on +44 (0) 2071111105 or via email at support@bmj.com.

Visit casereports.bmj.com for more articles like this and to become a Fellow 